\title{
Interactive comment on "Cloud Condensation Nuclei properties of South Asian outflow over the northern Indian Ocean during winter" by Vijayakumar S. Nair et al.
}

Vijayakumar S. Nair et al.

vijayakumarsnair@gmail.com

Received and published: 28 January 2020

The comment was uploaded in the form of a supplement: https://www.atmos-chem-phys-discuss.net/acp-2019-828/acp-2019-828-AC1supplement.pdf

Interactive comment on Atmos. Chem. Phys. Discuss., https://doi.org/10.5194/acp-2019-828, 2019. 